\title{
GAN Gene
}

National Cancer Institute

\section{Source}

National Cancer Institute. GAN Gene. NCI Thesaurus. Code C106422.

This gene plays a role in both neurofilament structure and ubiquitination. 